\title{
SUBROGACE V OBLASTI POJIŠŤOVNICTVÍ SE ZAMĚŘENÍM NA MEZINÁRODNÍ PRVEK*
}

\author{
MILAN BAKEŠ \\ ROMAN VYBÍRAL
}

\begin{abstract}
Subrogation in the Field of Insurance with a Focus on the International Element
The issue of subrogation is to a large extent specific, especially in the field of insurance. The article looks at this institute from a theoretical and practical point of view. The authors try to introduce a theoretical classification of subrogation, to analyze national legislation in the field of insurance and to describe selected problematic issues of national legislation. At the same time the authors focus on the practical consequences of the presence of an international element in the subrogation relationship.
\end{abstract}

Keywords: subrogation; insurance; international element

Klíčová slova: subrogace; pojištění; mezinárodní prvek

DOI: $10.14712 / 23366478.2020 .20$

\section{1. ÚVOD}

V moderním globalizovaném světě je přeshraniční přesah většiny finančních produktů, resp. produktů typických pro finanční trhy naprosto běžný. Výjimku netvoří ani pojistné produkty, které si kladou za cíl zejména eliminovat rizika spojená s určitou činností. ${ }^{1} \mathrm{~V}$ důsledku této skutečnosti nastávají v praxi poměrně běžně situace, kdy existence mezinárodního prvku značně znesnadňuje aplikaci příslušných právních norem, a to s ohledem na jejich obtížnou identifikaci pramenící z existence vícero v úvahu přicházejících jurisdikcí. Tento mezinárodní prvek přitom může spočívat v domicilu stran pojistné smlouvy (zejména u významnějších pojistných vztahů je běžné, že jsou pojistník a pojistitel entitami z různých zemí), v charakteru pojištěné činnosti nebo

\footnotetext{
* Tento text byl zpracován v rámci programu „PROGRES Q02 - Publicizace práva v evropském a mezinárodním srovnání” realizovaného na Právnické fakultě Univerzity Karlovy. ORCID autorů: 0000-0002-3836-3849 (prof. JUDr. Milan Bakeš, DrSc.); 0000-0002-1112-408X (JUDr. Roman Vybíral, Ph.D.).

1 Viz KARFÍKOVÁ, M. - PŘIKRYL, V. - VYBÍRAL, R. a kol. Pojišt’ovací právo. 2. přepracované vydání. Praha: Leges, 2018. s. 14 a násl.
} 
majetku (opět zejména ve vztahu k vysoce rizikovým aktivitám, případně ve vztahu k rozsáhlejším majetkovým hodnotám), v místě vzniku újmy apod. Jedním z případů, kdy je někdy nezbytné se vypořádat s existencí mezinárodního prvku v oblasti pojišt'ovnictví, je případ tzv. subrogace, neboli přechodu práva z jedné osoby (obvykle pojistníka) na druhou osobu (typicky pojistitele), a to v souvislosti s uskutečněnou výplatou pojistného plnění. V obecné teoreticky zaměřené části se autoři zamýšlí nad tím, zda lze případy subrogace $\mathrm{v}$ oblasti pojišt'ovnictví vnitřně klasifikovat, případně na základě jakých kritérií. Autoři si dále kladou za cíl analyzovat problematiku rozhodného práva $\mathrm{v}$ případech subrogace $\mathrm{v}$ oblasti pojišt'ovnictví se zaměřením na případy s mezinárodním prvkem, a to zejména na základě analýzy jednotlivých právních norem ve vazbě na tuzemské právo. Autoři si stanovili hlavní hypotézu, kterou je otázka, zda je současná právní úprava zcela jednoznačná z pohledu adresátů norem, a to zejména s ohledem na hierarchickou strukturu právních norem, kdy mohou nastávat vnitřní konflikty, které mohou snadno vyústit v nesprávnou interpretaci těchto norem ve svém celku.

\section{PRINCIPY SUBROGACE A JEJÍ ČLENĚNÍ V RÁMCI POJIŠŤOVNICTVÍ}

Subrogaci lze vymezit jak teoreticky, tak prakticky. Z teoretického hlediska se jedná o formu nahrazení jedné z osob závazku osobou odlišnou, a to při zachování původních práv a povinností. ${ }^{2}$ Pokud jde o pozitivně-právní hledisko, lze odkázat např. na čl. 15 nařízení Evropského parlamentu a Rady (ES) č. 593/2008 ze dne 17. června 2008 o právu rozhodném pro smluvní závazkové vztahy (Řím I) (dále také jen „,nařízení Řím I“), kde se k tzv. zákonné subrogaci v oblasti smluvních vztahů uvádí, že ,,(m) á-li určitá osoba (,věritel') smluvní pohledávku vưči jiné osobě (,dlužníkovi“), a třetí osoba je povinna uspokojit věritele nebo na základě této povinnosti věritele uspokojila, určuje právo, kterým se řídí povinnost této třetí osoby, zda a v jakém rozsahu je třetí osoba oprávněna uplatnit vůči dlužníkovi práva, která měl věřitel vi̊či dlužníkovi podle práva rozhodného pro jejich vztah". Na podobném principu je vybudován rovněž čl. 19 nařízení Evropského parlamentu a Rady (ES) č. 864/2007 ze dne 11. 7. 2007, o právu rozhodném pro mimosmluvní závazkové vztahy (Řím II) (dále také jen „nařizení Řím $\left.I I^{*}\right)$, kde je subrogace v oblasti mimosmluvních vztahů vymezena následovně: ,„(m)á-li určitá osoba (,věritel') mimosmluvní nárok vưči jiné osobě (,dlužníkovi“) a třetí osoba je povinna uspokojit věritele nebo na základě této povinnosti věritele uspokojila, určuje právo, kterým se řídí povinnost této třetí osoby, zda a v jakém rozsahu je třetí osoba oprávněna uplatnit vi̊či dlužníkovi práva, která měl vůči dlužníkovi věritel podle práva rozhodného pro jejich vztah". Pokud jde o tuzemskou právní úpravu, o subrogaci se hovoří např. ve vztahu k $\$ 1937$ odst. 2 zákona č. 89/2012 Sb., občanský zákoník (dále také jen „,NOZ“), který ve vztahu k plnění závazku třetí osobou namísto dlužníka uvádí, že „,(s)plněním dluhu vstupuje tato osoba do práv věritele a má právo, aby jí dlužník

2 Ze zahraniční teorie lze jako př́klad uvést publikaci HORN, R. C. Subrogation in Insurance. Theory and Practice. Homewood (Illinois): University of Pennsylvania, 1964. 
vyrovnal, co za něho plnila. Pohledávka věritele na ni přechází včetně příslušenství, zajištění a dalších práv s pohledávkou spojených. Věritel vydá tomu, kdo za dlužníka plnil, potřebné doklady o pohledávce a sdělí mu vše, co je k uplatnění pohledávky zapotřebi". Speciálně v oblasti pojišt'ovnictví vykazuje subrogace určitá specifika např. ve vztahu k pojištění odpovědnosti za škodu způsobenou provozem vozidla, kdy bývá v praxi mezinárodní prvek přítomen poměrně často. ${ }^{3} \mathrm{Z}$ výše uvedeného vyplývají dva dílčí závěry, a to ten, že subrogace aktuálně není v českém právu jednotně zakotvena, a ten, že existuje více druhů subrogace. Autoři dospívají ke čtyřem hlavním způsobům kategorizace. Lze hovořit o subrogaci latentní (tj. prozatím neaktivní, nicméně v budoucnu možné) a aktivní (v případě, kdy již došlo k naplnění podmínek pro její aktivaci). Dále lze hovořit o subrogaci v oblasti smluvních vztahů (tato pramení ve smluvní volnosti stran) a mimosmluvních vztahů (např. v oblasti náhrady způsobené újmy). Další způsob kategorizace spočívá ve členění na subrogaci jednotnou (zde se na veškeré vztahy související se subrogací uplatní právní režim jedné země) a hybridní (zde dochází v rámci subrogace ke kombinaci právních řádů více zemí). Poslední kategorizace spočívá v dělení na subrogaci vzniklou ze zákona (k subrogaci dochází bez dalšího okamžikem naplnění stanovených podmínek) a smluvní (k subrogaci dochází na základě dohody zainteresovaných stran). Pro sektor pojišt’ovnictví je typická aktivní zákonná subrogace v oblasti mimosmluvních vztahů, konkrétně nejčastěji v oblasti náhrady škody (resp. újmy). V tuzemském právu je tento princip obsažen v $\$ 2820$ NOZ. Latentní subrogace v českém právu umožněna není, byt' může z textace uvedeného ustanovení vyznívat bez bližší analýzy opak, a to s ohledem na to, že je subrogace vázána toliko na výplatu pojistného plnění. Současně může jít o subrogaci jednotnou i hybridní. Právě hybridní subrogace s sebou v praxi může přinášet řadu sporných otázek.

\section{SUBROGACE V POJIŠŤOVNICTVÍ PODLE ČESKÉHO PRÁVA}

Dnes je problematika subrogace v českém právním řádu upravena v $§ 2820$ NOZ. V odst. 1 daného ustanovení se konstatuje, že ,(v)zniklo-li v souvislosti s hrozící nebo nastalou pojistnou událostí osobě, která má právo na pojistné plnění, pojištěnému nebo osobě, která vynaložila zachraňovací náklady, proti jinému právo na náhradu škody nebo jiné obdobné právo, přechází tato pohledávka včetně př́slušenství, zajištění a dalších práv s ní spojených okamžikem výplaty plnění z pojištění na pojistitele, a to až do výše plnění, které pojistitel oprávněné osobě vyplatil. (...)“. Nutno podotknout, že obdobný princip s obvykle velmi obdobnou textací bývá obsažen v řadě zahraničních právních úprav ${ }^{4}$ a jedná se tak o obvyklý a tradiční institut (na území dnešní České republiky je znám ve své moderní podobě bezmála sto let). „Tradice tohoto právního institutu však není nijak samoúčelná; naopak se jedná o institut zcela nutný a nezbytný pro správnou funkčnost celého právního systému reparace majetkových újem nastávajicích

\footnotetext{
K tomu viz např. rozsudek Nejvyššího soudu ze dne 15. prosince 2015, sp. zn. 23 Cdo 4210/2013.

4 Jako př́íklad lze uvést § 813 slovenského zákona č. 40/1964 Zb., občiansky zákonník, příp. § 965 občanského zákoníku Ruské federace.
} 
v lidské společnosti (...). "5 Institut subrogace současně komplexně řeší dva problémy, a to bezdůvodné obohacení a náhradu újmy. Újma typicky vzniká na straně pojistníka např. z důvodu poškození nebo zničení věci. Takto vzniklá újma (resp. škoda) může být pojistníkovi (př́íp. jiné osobě) kompenzována výplatou pojistného plnění. V případě, kdy však za vzniklou újmu odpovídá třetí osoba, je nezbytné tuto skutečnost brát v potaz a nastalou situaci řešit komplexně. Spokojením se toliko se skutečností, že pojistník obdržel pojistné plnění a jeho újma byla reparována, by došlo k tomu, že osoba odpovědná za škodu by z uvedené situace vyvázla bez postihu, nebot' finančně by daná situace tížila pouze pojistitele. Občasné tendence směřovat finanční břemeno na pojistitele přitom nepochybně nejsou opodstatněné. Subrogace v sobě současně z pohledu pojistitele skrývá několik komplikací, s nimiž se musí vyrovnat. Jedním z takových rizik je skutečnost, že po výplatě pojistného plnění se pojistitel dostává do role původního poškozeného (pojistníka) s tím, že výsledky následného subrogačního postupu nejsou známy (není zajištěno, že bude pojistitel následně skutečně uspokojen), což může mít pro pojistitele negativní finanční dopady. Dalším z rizik je skutečnost, že je na pojistiteli, aby pojistnou událost šetřil s nejvyšší péčí, nebot' v případě zjištění skutečnosti, že pojistné plnění nemělo být vyplaceno, případně mělo být vyplaceno v nižší výši, z povahy věci k subrogaci plně nebo zčásti nedojde. Tato skutečnost má za následek, že by měl pojistitel řešit neoprávněně vyplacené pojistné plnění, což může být např. z důvodu promlčení obtížné po právní stránce, současně není v mnoha případech vhodné řešit tuto vratku pojistného plnění ani politicky. V této souvislosti vyvstává otázka, zda je soud nebo jiný orgán, resp. jiná osoba řešící případný subrogační spor, oprávněna věcně řešit rovněž oprávněnost výplaty pojistného plnění, tedy dílčí příčinu subrogace. Autoři se domnívají, že tuzemská právní úprava tento postup neumožňuje, a to s ohledem na skutečnost, že druhou z dílčích příčin subrogace je existence práva na náhradu škody, resp. jiného obdobného práva. S ohledem na to, že subrogační vztah není vztahem originárním, nýbrž derivativním od vztahu primárního (tedy typicky vztahu mezi škůdcem a poškozeným), není rozhodující, který ze subjektů předmětné právo uplatňuje, tedy zda poškozený, nebo jeho pojistitel.

\section{MEZINÁRODNÍ PRVEK V RÁMCI SUBROGACE}

Jak bylo avizováno v úvodu příspěvku, právě přítomnost mezinárodního prvku často činí ze subrogace velmi obtížný vztah, nebot' obvykle dochází ke střetu vícera kolizních norem na několika úrovních (vnitrostátní právo, unijní právo, mezinárodní právo soukromé). $\mathrm{V}$ případě nejčastějších důvodů vzniku subrogace $\mathrm{v}$ oblasti pojištění (tj. odpovědnost za újmu a uhrazené pojistné plnění z titulu majetkového pojištění) by bylo možné hovořit o využití kolizních norem obsažených v zákoně č. 91/2012 Sb., o mezinárodním právu soukromém, ve znění pozdějších předpisů (dále také jen „ZMPS“). ZMPS však na rozdíl od svého předchůdce ${ }^{6}$ úpravu kolizních norem pro

5 Viz HAAS, K. Komentář k § 2820. In: ŠVESTKA, J. - DVOŘÁK, J. - FIALA, J. a kol. Občanský zákoník - komentářr. Svazek VI (relativní majetková práva). Wolters Kluwer, 2014.

6 Zákon č. 97/1963 Sb., o mezinárodním právu soukromém a procesním, ve znění pozdějších předpisů. 
standardní mimosmluvní závazky neobsahuje. Se vstupem do Evropské unie se stalo pro oblast kolizních norem v mimosmluvních vztazích klíčové nařízení Řím II, a to i pro vztahy působící navenek Evropské unie. Nařízení Řím II přitom v čl. 19 rozlišuje dvě fáze subrogace, ${ }^{7}$ což může vyústit v použitelnost dvou právních řádů (tzv. hybridní subrogace). Pokud se jedná o právní řád určující, zda a v jakém rozsahu je pojistitel oprávněn uplatnit pohledávku pojistníka vůči osobě odpovědné za vzniklou újmu, je jím právní řád, kterým se řídí povinnost pojistitele vůči pojistníkovi (tzv. statut základu cese). Tímto právním řádem je právo rozhodné pro pojistnou smlouvu mezi pojistníkem a pojistitelem. Pokud jde o právní řád určující podmínky práva na náhradu újmy (resp. obdobného práva), nařízení Řím II zde odkazuje na právní řád rozhodný pro mimosmluvní vztah mezi věřitelem (typicky poškozeným) a dlužníkem (typicky škůdcem). Při řešení rozhodného práva (resp. rozhodných práv) pro každý jednotlivý případ je tedy nezbytné zkoumat jak právo rozhodné pro vztah mezi pojistníkem a pojistitelem založený typicky pojistnou smlouvou (zde bývá obvykle rozhodné právo výslovně uvedeno a tato otázka tak v praxi nečiní zásadní obtíže), tak právo rozhodné pro původní mimosmluvní vztah typicky mezi poškozeným a škůdcem. Zde je pro zjednodušení vhodné založit fikci neexistence pojistného vztahu a řešit tento vztah izolovaně. Velmi často se jedná o odpovědnostní vztahy za újmu (resp. škodu), na které je běžně pamatováno jak ve vnitrostátních právních řádech, tak v nařízení Řím II, případně mohou přetrvávat mezinárodní smlouvy uzavřené nejčastěji před vstupem do Evropské unie, které mají v souladu s čl. 28 odst. 1 nařízení Řím II aplikační přednost ve vztazích s mimo unijním státem. Př́kladem takové smlouvy může být smlouva mezi Československou socialistickou republikou a Svazem sovětských socialistických republik o právní pomoci a právních vztazích ve věcech občanských, rodinných a trestních, vyhlášená Ministerstvem zahraničních věcí dne 16. 5.1983 pod č. 95/1983 Sb. (dále také jen ,smlouva o právní pomoci“). V souladu s čl. 38 odst. 1 smlouvy o právní pomoci se nárok poškozeného na náhradu škody řídí právním řádem smluvní strany, na jejímž území došlo k jednání nebo k události zakládající nárok na náhradu škody. Hraničním určovatelem je zde lex loci delicti comissi, tedy místo, kde došlo k jednání nebo události zákládající nárok na náhradu škody - tedy ke spáchání deliktu. Při neexistenci zvláštní mezinárodní smlouvy pak dojde nejčastěji k uplatnění obecného pravidla obsaženého v čl. 4 nařízení Řím II. Teprve na základě rozčlenění nastalého typizovaného trojstranného vztahu mezi pojistitelem, pojistníkem (poškozeným) a škůdcem na vztahy dílčí může dojít k řešení rozhodného práva, resp. rozhodných práv pro vzniklý subrogační vztah. Na závěr autoři podotýkají, že výše uvedené závěry někdy v praxi narážejí na obtíže s vymezením přesných hranic mezi oběma složkami postupu, které jsou zakotveny v čl. 19 nařízení Řím II. Pro úplnost autoři dodávají, že úprava obsažená v čl. 7 nařízení Řím I se na subrogační mimosmluvní vztahy s ohledem na svou povahu neaplikuje. ${ }^{8}$

7 Viz TICHÝ, L. Nařízení Řím II: Komentář. Praha: C. H. Beck, 2018, s. 214 a násl.

8 K tomu blíže např. viz DOBIÁŠ, P. Mezinárodní pojistné právo. Praha: Leges, 2012, s. 51 a nás1. 


\section{ZÁVĚR}

Autoři si v úvodu práce stanovili hypotézu, která zněla, zda je současná právní úprava zcela jednoznačná z pohledu jejích adresátů, a to zejména s ohledem na hierarchickou strukturu právních norem. V této souvislosti dospívají k závěru, že v případech, kdy je jedním z mezinárodních prvků prvek tuzemský, což vede k alespoň částečné aplikaci tuzemských právních norem, je tato situace někdy poměrně komplikovaná a velmi nepatrná nuance konkrétního př́ipadu dokáže odchýlit pomyslný jazýček na vahách, což povede ke stanovení odlišného rozhodného práva oproti původním předpokladům. Problémy mohou nastávat zejména v případech, kdy jsou konkrétní situace pokryty duplicitně, a to jak na úrovni norem unijního práva, tak práva mezinárodního, v podobě znění uzavřených mezinárodních smluv. Správné stanovení postupu vedoucího k určení rozhodného práva v rámci nastalé subrogace je přitom zcela klíčové a má vliv na samotnou existenci nároku, jeho promlčení, jeho př́ípadnou vymahatelnost apod. Autoři se současně domnívají, že i přes výkladové obtíže není na místě činit případné legislativní kroky. Je však vždy třeba pečlivě posuzovat znění rozhodujících právních předpisů, být obeznámen s existencí případných mezinárodních smluv, které mohou mít aplikační přednost před unijním právem, znát aktuální závěry judikatury a dokázat interpretovat často ne zcela jasné právní pojmy v souladu s doktrínou a judikaturou nejvyšších soudních instancí. Ani to však někdy zcela nevyloučí možný odlišný výklad soudu nebo rozhodce. Nastalé spory poté mohou být velmi obtížné, a ačkoliv nejde o téma nikterak nové, doktrína a rozhodovací praxe se stále formuje, přičemž autoři věří, že tomuto formování budou rovněž nápomocni.

Prof. JUDr. Milan Bakeš, DrSc.

Právnická fakulta Univerzity Karlovy

bakes@prf.cuni.cz

orcid.org/0000-0002-3836-3849

JUDr. Roman Vybíral, Ph.D.

Právnická fakulta Univerzity Karlovy

vybiralr@prf.cuni.cz

orcid.org/0000-0002-1112-408X 